\title{
REVIEW.
}

The Naval Hospital Ship: Fitting Out and Administration of a Naval Hospital Ship. By Fleet-Surgeon Edward Sutron, R.N. Bristol : John Wright \& Sons, Ltd. Pp. 110 . Price 8s. net.

Fleet-Surgeon Edward Sutton, R.N., having served in three naval hospital ships during the war, is well qualified to write this monograph. The evolution of hospital ships and their use and abuse in war according to the Geneva Convention are first described. Thereafter is a detailed account of the conversion of s.s. "Driana" into a naval hospital ship. This is followed by a full and clear statement of ordinary and emergency administrative duties. The organisation described for keeping records of patients and stores alike is very efficient, and the book should be of great assistance to the medical staff of hospital ships.

The author remarks that, owing to administrative duties, he was completely debarred from participating in clinical work, but nevertheless some of the clinical arrangements described in his book are open to criticism. Thus one medical officer did $X$ rays and intravenous injections of galyl, whilst another was in charge of the venereal and mental wards. If one of these medical officers was a syphilogist, his duties might naturally have included both the venereal ward and specific treatment. Another medical officer was in charge of the laboratory and also of the tuberculous ward, an appointment which would demand expert knowledge in two highly specialised branches of medicine. It is possible that in this particular instance the dual qualification was available. In general, it would appear that the idea of specialism has ret to be developed in the Naval Medical Service, where officers are expected to profess an all-round proficiency to which no civil practitioner could possibly attain.

Halliday Sutherland, R.N.

\section{NOTES AND QUERIES.}

\section{A Representative Council of British Ophthalmologists.}

A well-attended meeting of ophthalmic surgeons and physicians was held at the rooms of the Royal Society of Medicine on Thursday, May 2, for the purpose of forming a Representative Council, chosen from among members of the Specialty, empowered to take action in matters of ophthalmological interest arising in connection with publie affairs.

Mr. Treacher Collins, President of the Ophthalmological Society of the United Kingdom, was voted to the ehair.

The resolution affirming that such a Council should be formed was proposed by Sir Anderson Critchett, Bt., C.V.O. He said it would meet a definite need, and would tend to weld the elements of ophthalmology more closely together, as well as making for the welfare of the public.

Mr. Richardson Cross (Bristol) seconded the resolution, remarking that Governments and governing bodies required expert advice in order to be efficient, and the best experts were those who enjoyed the confidence of their colleagues in that special line of practice. Owing to the amalgamation of the journals devoted to ophthalmology into one organ, and the representation on the Ophthalmological Society of the various similar bodies in the kingdom, the profession was now well organised, and could present a powerful front on all questions specially concerning it. He instanced ophthalmia neonatorum, Army and Navy visual standards, visual and lighting requirements in various kinds of industry, organised inquiries con. cerning the blind, grades of compensation payable according to degrees of visual disability, and so on.

Mr. J. B. Lawford, in supporting the resolution, said the days were rapidly passing when we could afford to ignore scientific discoveries and the new methods based upon them, and he believed more attention would be paid in the future to 
the views of representative bodies, and less to the opinions of individuals, how ever eminent. The State was now, more and more, assuming the rote of parent, and, like other parents, would be all the better for sound advice. He would like to see ophthalmology made a compulsory subject of the medical curriculum, a matter on which we were much behind other civilised countries. At present a man receiving the minimal qualifying medical diploma conld at once take up the practice of ophthalmology, and if the proposed Committee should do no more than insist that men should not take up this work without special training, it would fully justify its formation.

Supporting speeches were made by Mr. Grey Clegg (Manchester), Sir George Berry, and Dr. G. Mackay (Edinburoh), and the resolution was carried unanimonsly.

It was further decided that the Council should consist of all the past and present Presidents of the Ophthalmological Society of the United Kingdom and of the Section of Ophthalmology of the Royal Society of Medicine as permanent members, four members nominated annually by the Councils of each of these Societies, and one representative from the Oxford Ophthalmological Congress.

H. Dickinson.

(Approved by the Chairman.)

iWe congratulate the British ophthalmologists and suggest that British otolaryugologists follow their good example.

\section{A Simple Nasal "Splint."}

In a case with synechiæ of the nose recently under my care I tried, after division of the adhesions, the wearing of a "splint" made of a piece of rubber taken from the palm of an ordinary rubber glove. It was put in between the opposing surfaces in a vertical position and, being very flexible, required some care in adjustment. But it was comfortable to wear and answered perfectly. The patient only had to wear it about a week, and the adhesions did not re-form. I cleaned it and re-inserted it daily.

Dan McKenzie.

Newspaper Publisher's “Shipwreck Cure” For Deapness.

'The death is announced of Mr. William Isaac Iliffe, head of the firm of Iliffo and Sons, printers and publishers, of London and Coventry, at the age of seventyfour.

Mr. Iliffe had not for some years past taken mnch active part in the management of the business, spending his days quietly at his home at Coventry, where he died.

His firm owned the Midland Daily Telegraph, which is published at Coventry.

Mr. Iliffe was one of the passengers on the steamship " Stella," belonging to the London and South-Western Railway Company's Channel Island service, which was wrecked off the Casquets on the afternoon of March 30, 1899, when about ninety lives were lost.

He used to tell how he managed to keep afloat by clinging to a furniture van until he was rescued. At the time of the disaster he suffered from partial deafness, but the shock of the accident restored his full hearing for a long time, and it was one of his little jokes to recommend anyone whose hearing was defective to try a shipwreck as an infallible remedy.

A patient with malignant disease of the throat went many years ago to consult a surgeon who had devoted much attention to laryngeal disease. The surgeon examined the case, gave his diagnosis, and recommended removal of the larynx. The patient expressed a fear that the operation was very dangerous. "Oh, no," said the surgeon, "you are sure to recover." "But," said the patient, "I understood that the operation was very serious indeed." "Well," said the surgeon, "my reason for saying that you are sure to recover is this: the mortality is 19 out of 20 and I've had 19 deaths already."

\section{BOOKS RECEIYED.}

Studies in the Anatomy and Surgery of the Nose and Ear. By Adam E. Smith, M.D. New York. 1918. Price \$4.00.

Eye, Ear, Nose, and Throat: $A$ Manual for Students and Practitioners. By Howard Charles Ballenger, M.D., and A. G. Wippern, M.D. New Second Edition. Lea and Lebiger, Philadelphia and New York. 1917. 


\title{
Lancet.--"We have nothing but praise for this Annual."
}

\author{
THIRTY-FIFTH YEAR. \\ NOW READY. \\ Fully Illustrated in Colours and Black and White. \\ Price 10/- net.
}

\section{THE \\ MEDICAL AL ANNUAL, \\ 1917.}

\author{
A YEAR BOOK OF TREATMENT, \\ AND PRACTITIONER'S INDEX: \\ Being a Review of the World's Progress in Medicine and Surgery, \\ arranged in Alphabetical order for Easy Consu tion.
}

\section{Contributors :}

E. WYLLYS ANDREWS, A.M., M.D., Chicago. JOSEPH G. BLOMFIELD, B.A., M.D. FRANCIS D. BOYD, C.M.G., M.D., F.R.E.P. FRANCIS J. CHARTERIS, M.D., B.CH. JOHN D. COMRIE, M.A., M.D., F.R.C.P. LEWIS A. CONNER, PH.B., M.D., New York. CAREY F. COOMBS, M.D., F.R.C.P.

W. H. DOLAMORE, M.R.C.S., L.R.C.P., T..D.S.R.C.S. JOHN S. FRASER, M.B., CH.B., F.R.C.S.

W. E. HOTHERGILL, A.A., M.D.

DAVID MCV. FLECK, M.в., СH. в.

HERBERT FRENCH, M.A., M.D., F.R.C.P.

EDWARD W. GOODALI, M.D., B.S.

C. THURSTAN HOLLAND, M.R.c.s., l.R.c.p.
J. RAMSAY HUNT; M.D., New York.

ROBERT HUTCHISON, M.D., F.R.C.P.

FREDERICK LANGMEAD, M.D., F.R.C.P.

E. G. GRAHAM LITTLE, M.D., F.R.c.P.

CHARLES FREI). MARSHALL, M.D., F.R.C.

BEDFORD PIERCE, M.D., F.R.C.P.

JOSEPH PRIESTLEY, B.A., M.D., D.P.H.

SIR LEONARD ROGERS, Lt.Col, t.M.S., M.D F.R.C.S., F.R.C.P., Calcutta.

A. HUGH THOMPSON, M.A., M.D.

J. W. THOMSON WALKER, F.R.C.s.

W. I. DE COURCY WHEELER. B.A., M.D., F.R.C.S A. GASCOIGNE WILDEY, Dep. Surg.Gen., R.N. MARGUERITE WILSON, м.в., Сн.в., Glasgow.

\section{THIS year's volume aims, like its predecessors, to be a faithful reflex of current Medical and Surgical thought. It is, therefore, of necessity coloured by the consideration of the many new problems which are thrust upon us by the War. These problems will confront the general Practitioner on every hand, and he must be prepared to deal with them. \\ Hence the current volume has a unique value, in that it furnishes the reader with a careful review of the latest achievements in War Surgery and Medicine, which will be of value now and in the years to come, and which cannot be obtained from any other source. \\ The civil side of the Practitioner's work has, of course, not been neglected. \\ The new "Annual" continues to be, as in the past, a digest of the best modern teaching culled by experts from the medical literatnre of the world.}

BRISTOL, ENG. : JOHN WRIGHT \& SONS LTD.

LONDON: SIMPKIN, MARSHALL, HAMILTON, KENT \& CO. LTD. 


\section{Dr. Irwin Moore's UNIVERSAL FORCEPS}

For Removing Foreign Bodies from the CEsophagus, Trachea, or Bronchi,

\section{And ENDOSCOPIC CUTTING FORCEPS or SHEARS}

And

For Cutting through Tooth-plates, Pins, or Bones.

\section{Dr. William Hill's EXPANDING CESOPHAGOSCOPE}

For assisting in Removal of Impacted Tooth-plates, etc.

See LANCET, May 13th, 1916.
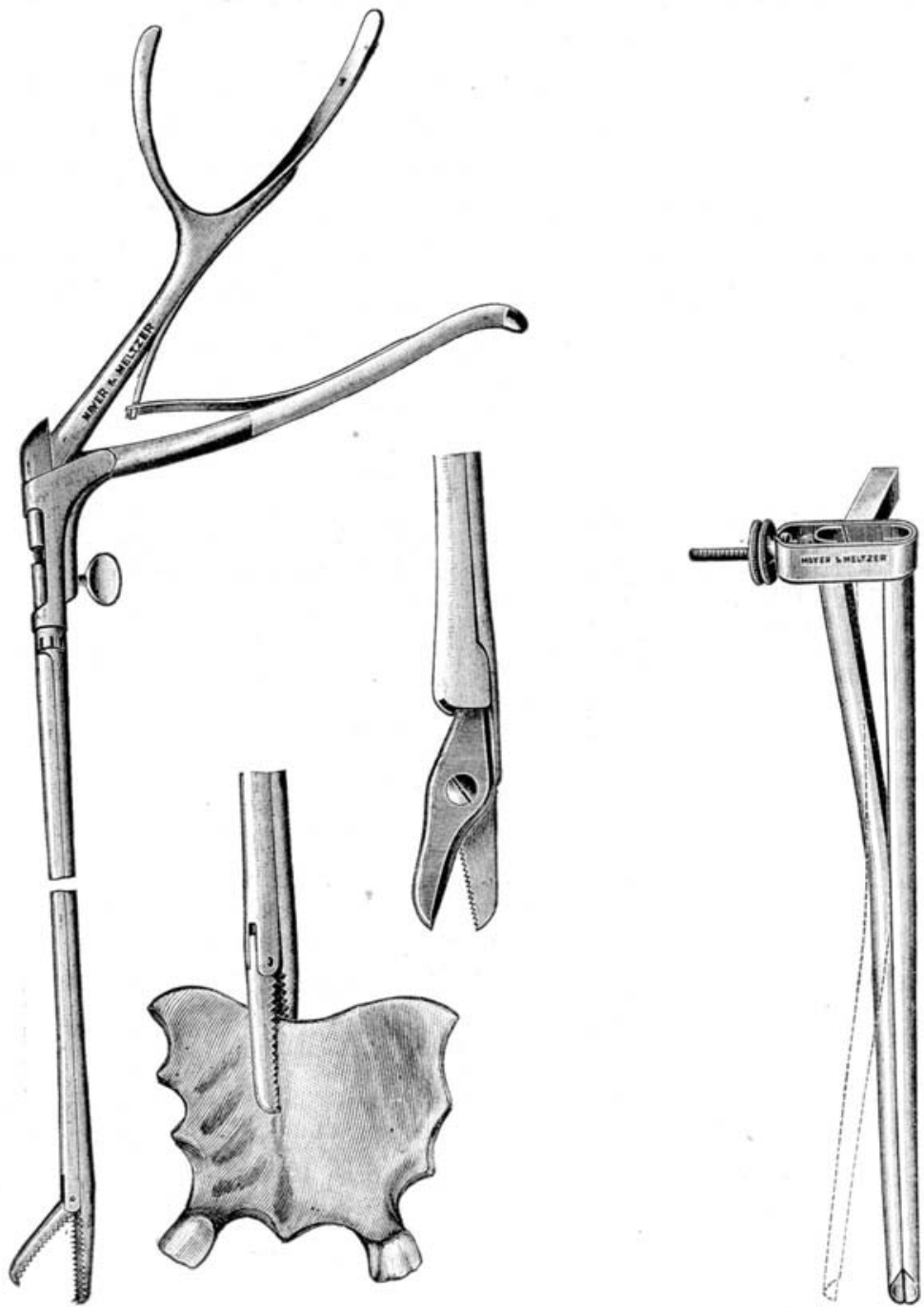

FULL PARTICULARS ON APPLICATION.

MAYER \& MELTZER, 71, GT. PORTLAND ST., LONDON, W. 


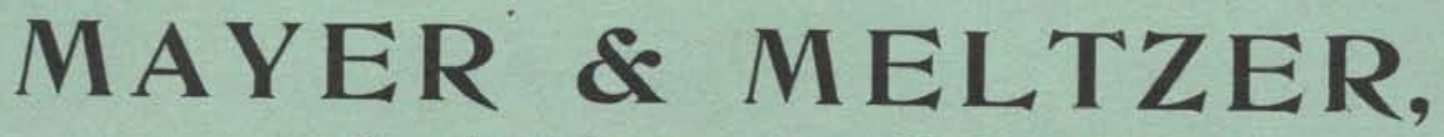

Surgical Instrument Makers.

ESTABLISHED OVER FIFTY YEARS.

\section{Regulating Apparatus for the}

\section{Administration of Warm Anasthetic Vapours.}

(Vide article in LANCET, Jan. 8th, 1916, by Francis E. Shipway, M.A., M.D.Cantab.)

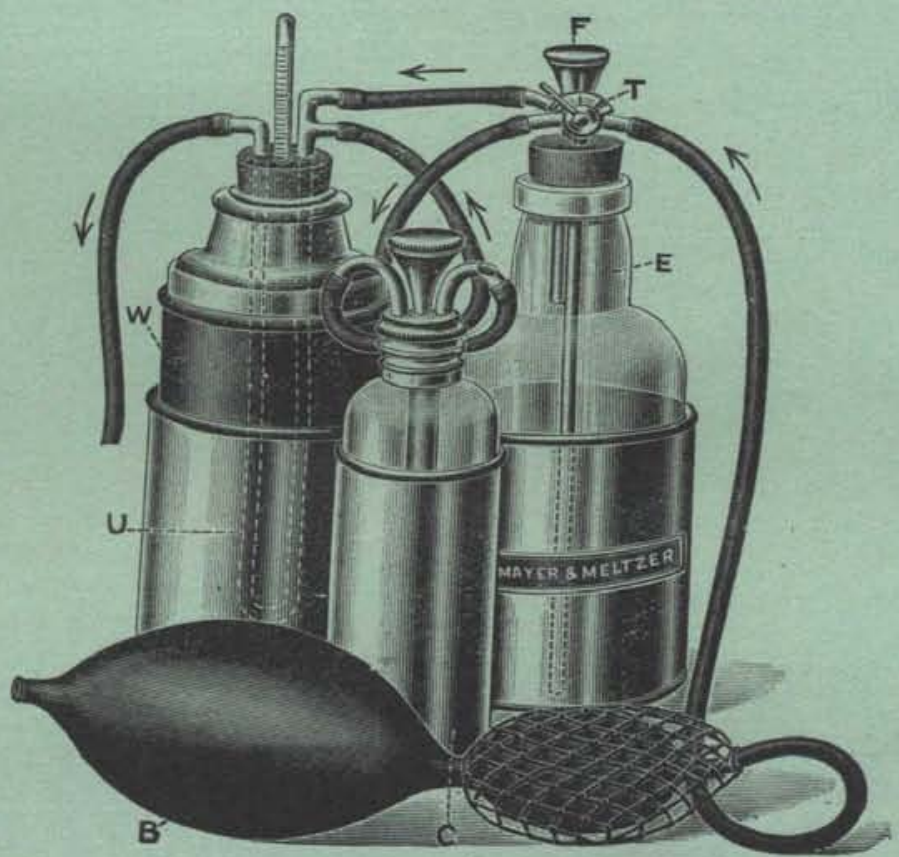

The Administration of Warm Ether Vapour has all the advantages of the Open Ether Method, and is safer. There is less loss of body heat, less shock, less consumption
of the anæsthetic.

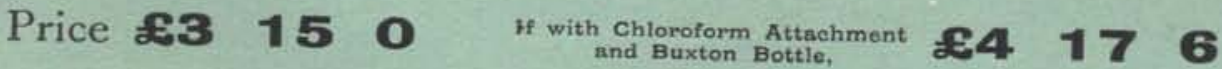

MAYER \& MELTZER, 7I, GREAT PORTLAND ST., LONDON. Contractors to the War Office. 


\section{The "Allenburys" (mencrarze) Throat Pastilles}

Effrient

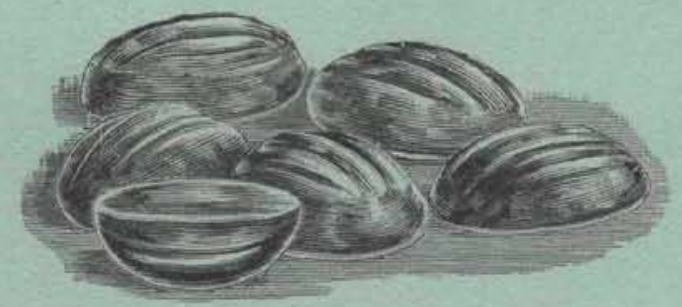

Palatable

The basis of the "Allenburys" Throat Pastilles is a special pâte de jujube. The pastilles are demulcent, soluble and palatable, and contain accurate amounts of pure active drugs. They dissolve slowly and uniformly, so ensuring the thorough suffusion of the mucous membrane, and the prolonged continuous direct effect of the active ingredients.

The following pastilles are largely used, and have been found from long practical experience to be very efficacious.

No. 9. Menthol, Cocaine and Red Gum

No. 23. Eucalyptus and Red Gum

Menthol, gr. 1/20th: Cocaine, \&r. 1/40th; Red Gum, Rr. 2

No. 28. Compound Guaiacum

No. 29. Compound Rhatany

No. 38. Chlorate of Potash, Borax and Cocaine

No. 75. Formaldehyde and Menthol

Formaldehyde, min. 1: Menthol, gr. 1/40th

No. 77. Formaldehyde and Cinnamon Oil

Formaliehyde, min. 1; Ot. Cinnamon, min. $\frac{1}{2}$

A detailed list of the varieties made will be sent on application.

IMPORTANT.-To ensure the supply of these active and reliable medicinal products, medical men should designate the

"ALLENBURYS" Pastilles in their prescriptions.

\section{Allen \& Hanburys Itd. London

